\title{
Dendrochronology-based fire history of J effrey pine - mixed conifer forests in the Sierra San Pedro Martir, Mexico
}

\author{
Scott L. Stephens, Carl N. Skinner, and Samantha J . Gill
}

\begin{abstract}
Conifer forests in northwestern Mexico have not experienced systematic fire suppression or logging, making them unique in western North America. Fire regimes of Pinus jeffreyi Grev. \& Balf. mixed conifer forests in the Sierra San Pedro Martir, Baja California, Mexico, were determined by identifying 105 fire dates from 1034 fire scars in 105 specimens. Fires were recorded between 1521 and 1980 and median fire return intervals were less than 15 years at all compositing scales. Significant differences in mean fire return intervals were detected from 1700 to 1800,1800 to 1900 , and 1900 to 1997 , most often at intermediate spatial compositing scales, and the proportion of trees scarred in the fires of the $1700 \mathrm{~s}$ was significantly different from the fires of either the $1800 \mathrm{~s}$, the $1900 \mathrm{~s}$, or the combined post1800 period. Superposed epoch analysis determined that moderate and large spatial scale fires occurred on significantly dry years during the length of the record, but before 1800, these fires were preceded by significantly higher precipitation 1 year before the fire. The dominance of earlywood fires in the Sierra San Pedro Martir is similar to the seasonality found in the southwest United States and is different from the western slope of the Sierra Nevada and Klamath Mountains of California.
\end{abstract}

Résumé : Les forêts de conifères du Nord-Ouest du Mexique sont uniques dans l'Ouest de l'Amérique du Nord n'ayant pas été exploitées ni protégées contre les feux. Le régime des feux dans les forêts mixtes résineuses de Pinus jeffreyi Grev. \& Balf. situées dans la Sierra San Pedro Martir, dans la Basse-Californie au Mexique, a été établi en déterminant les dates de 105 feux à partir de 1034 cicatrices de brûlure présentes sur 105 spécimens. Des feux ont été identifiés de 1521 à 1980 et l'intervalle médian entre les feux était inférieur à 15 ans à toutes les échelles de composition. Des différences significatives dans les intervalles moyens entre les feux ont été observées de 1700 à 1800 , de 1800 à 1900 et de 1900 à 1997, le plus souvent à une échelle de composition spatiale intermédiaire, et la proportion des arbres avec des cicatrices de brûlure au cours des années 1700 était significativement différente de celles des années 1800,1900 ou de l'ensemble de la période postérieure à 1800 . Une analyse des époques superposées indique que des feux de moyenne et grande envergure spatiale sont survenus lors d'années particulièrement sèches pendant toute la période étudiée. Cependant, avant 1800 ces feux sont survenus après une année marquée par une précipitation significativement plus importante. La prépondérance des feux qui affectent les jeunes forêts dans la Sierra San Pedro Martir est comparable à la saisonnalité observée dans le Sud-Ouest des États-Unis et différente du régime qu'on observe sur les versants ouest de la Sierra Nevada et des Monts Klamath en Californie.

[Traduit par la Rédaction]

\section{Introduction}

To describe reference conditions, managers increasingly rely on photographic evidence, written historical accounts, and studies that reconstruct pre-fire-suppression conditions primarily from living and dead woody material (Fritts and Swetnam 1989; Swetnam et al. 1999). In doing so, it is often

Received 20 May 2002. Accepted 14 January 2003. Published on the NRC Research Press Web site at http://cjfr.nrc.ca on 13 May 2003.

S.L. Stephens. ${ }^{1}$ Department of Environmental Science, Policy, and Management, University of California, Berkeley, CA 94720-3114, U.S.A.

C.N. Skinner. United States Forest Service, Pacific

Southwest Research Station, Redding, CA 96001, U.S.A. S.J. Gill. Natural Resources Management and Bioresource and Agricultural Engineering Departments, California Polytechnic State University, San Luis Obispo, CA 93407, U.S.A.

${ }^{1}$ Corresponding author (e-mail: stephens@nature.berkeley.edu). assumed that prehistorical conditions would prevail today in the absence of fire suppression. However, the interaction of climatic variation and fire is complex (Swetnam 1993; Swetnam and Betancourt 1992, 1998; Grissino-Mayer and Swetnam 2000; Veblen et al. 2000; Flannigan et al. 2000), making it uncertain if similar prehistorical conditions would have occurred.

There has been considerable variation in climate over the last centuries (Swetnam and Betancourt 1998; Millar and Woolfenden 1999) that may have led to important changes in fire regimes (fire frequency, season, extent, etc.) and resulting forest conditions in the absence of fire suppression (Swetnam 1993; Stine 1996; Chang 1999). As a result, after nearly a century of fire suppression, there are few, if any, forests in western North America that could serve as models or "controls" for forests functioning under the continuing influence of climate variation and frequent fires (Skinner and Chang 1996; Minnich et al. 2000).

Conifer forests in isolated ranges of Mexico have not experienced systematic fire suppression or widespread logging (Minnich 1987; Fule and Covington 1999; Minnich et al. 
2000; Swetnam et al. 2001; Heyerdahl and Alvarado 2002). Although most have been grazed to varying levels of intensity, the absence of systematic fire suppression suggests that these forests may provide information useful for developing descriptions of reference conditions for similar forests in the United States.

Fire history studies have been conducted in many areas of the western United States to quantify prehistoric fire regimes (Heyerdahl et al. 1995; Skinner and Chang 1996). The majority of these studies use dendrochronology (the analysis of tree rings) to reconstruct fire history. Recently, several studies have used the analysis of aerial photographs to reconstruct fire history (Minnich and Chou 1997; Russel et al. 1998; Minnich et al. 2000).

Recent work by Minnich et al. (2000) contended that many fires documented using dendrochronology methods are of very limited size. They hypothesized these "spot" fires to be lightning strikes that scar individual trees and burn only a few square metres of forest. They suggested that such fires are insignificant ecologically, and when these small fires are included in composite chronologies (Dieterich 1980), past fire occurrence is overestimated.

Minnich et al. (2000) found the fire regime of the Sierra San Pedro Martir (SSPM) to be characterized mostly by large fires of mixed severity that occur less frequently than in many other pine-dominated forests of western North America before the policy of fire suppression was initiated. They further suggested that the fire regimes in other pinedominated forests that have been characterized as having more frequent fires are an artifact of methods used to create the fire history.

Minnich et al. (2000) have raised fundamental questions with regard to the use and interpretation of tree-ring analysis in fire history research. If, as they contended, their conclusions concerning fire size and frequency should be generically applied to pine-dominated forests throughout North America, then a substantial body of fire history literature based on fire scar analysis may be subject to reevaluation. However, they did not directly compare the results of their aerial photograph based fire history with a tree-ring based fire history. We believe such a comparison is necessary before such a sweeping disputation would be justified.

Similarly, some have questioned traditional sampling methods and past interpretations of data derived from fire scars in ponderosa pine (Pinus ponderosa Dougl. ex P. \& C. Laws.) forests of western North America (Baker and Ehle 2001). Although there are no ponderosa pine in the SSPM, the relationship of Jeffrey pine (Pinus jeffreyi Grev. \& Balf.) to fire is usually considered similar to that of ponderosa pine (Habeck 1992). However, there appears to be more variability in Jeffrey pine fire regimes in regions where the two species overlap (Skinner and Chang 1996).

One area of contention is that the time from pith to the first fire scar on a tree may be an indicator of the actual time necessary for sufficient fuel to build up so that fire would be able to burn adjacent to the tree. Some authors suggest that this period should be included in the calculation of fire return interval (FRI) statistics (e.g., Keeley and Stephenson 2000; Baker and Ehle 2001). However, our experience with fires leads us to believe that this is an unwarranted assertion. We suggest that the real fire-free interval is unknowable.
First, many trees in low- and moderate-intensity fires regularly survive many fires without ever developing scars. It is common for most trees to never scar over their lifetimes, although many fires burned through their stand. Second, many of the early scars on trees that record scars are often burned away by subsequent fires and cannot be determined from examination of the tree rings. In either case, the inclusion of the period from origin to first datable scar would likely overestimate the time without fire at the location of individual trees.

The time from pith to the first fire scar on a tree may be an indicator of past fire frequency in forests with thin-barked trees such as lodgepole pine (Pinus contorta Dougl. ex Loud. var. latifolia Engelm.). Lodgepole pine has thin bark even when mature; in contrast, most ponderosa and Jeffrey pines have a bark thickness of over $10 \mathrm{~cm}$ when mature (Burns and Honkala 1990). Thin bark throughout the life cycle of lodgepole pine would predispose it to scarring when subject to surface and ground fires. In contrast, when ponderosa and Jeffrey pines produce a moderate amount of bark, this would shield their cambium layers from injury unless locally high fuel loads produced a high amount of radiant energy to the stem. Steep slopes on the uphill side of the tree will also increase the probability of scarring because this geometry produces larger heat transfer shape factors (Incropera and de Witt 1990) and because fuel accumulates on the uphill side from gravity.

A second related area of contention concerns the use of fire scar composite chronologies (see Dieterich 1980) to estimate how often a sampled area burns (e.g., Baker and Ehle 2001). However, this becomes a problem only if the fire chronology is presented with all fires, even the smaller spot fires, and is interpreted by the reader as if the chronology indicates how often the entire stand burned. We agree that there is a potential problem if the data are interpreted in this way, since fires are quite variable in burn patterns. There is no way to know how completely a low- or moderate-severity fire burned a stand or landscape unless the patterns were recorded by witnesses. We agree with Baker and Ehle (2001) that it is appropriate to present fire regime statistics at several scales to provide evidence of variability in burn patterns.

The SSPM, with its absence of both logging and systematic fire suppression, provides the opportunity to address several questions: (i) what is the fire regime and how has it varied over time, (ii) how does the fire regime of the SSPM compare with fire regimes in California forests, and (iii) how does a tree-ring based description of the fire regime compare with a fire history that was based on the analysis of aerial photographs (i.e., Minnich et al. 2000)?

\section{Materials and methods}

\section{Study area}

The study was conducted in the SSPM National Park, located approximately $100 \mathrm{~km}$ southeast of Ensenada, Baja California, Mexico. Vegetation of the SSPM is composed of conifer forests and shrublands of the California floristic province that occur in no other area of Mexico (Minnich et al. 1995, 1997; Minnich and Franco 1998). Coniferous forests of the SSPM have only recently been described and 
cover approximately 40655 ha (Minnich 1987; Minnich et al. 2000). These forests are composed of Jeffrey pine, white fir (Abies concolor (Gord. \& Glend.) Lindl.), sugar pine (Pinus lambertiana Dougl.), lodgepole pine (Pinus contorta var. murrayana Dougl. ex Loud.), and limited amounts of incense-cedar (Calocedrus decurrens (Torr.) Floren.).

The most common forest types are Jeffrey pine, Jeffrey pine - mixed conifer, and mixed white fir forests, respectively (Minnich and Franco 1998). Elevation averages $2600 \mathrm{~m}$ in the north and decreases to $1800 \mathrm{~m}$ in the southern portion of the range. The highest mountains are over $3000 \mathrm{~m}$ in height. The soils of the SSPM are unclassified. The most common parent material is granite with some soils derived from metamorphic quartz shists. The mixed conifer forests of the SSPM have experienced neither tree harvesting nor a policy of largescale fire suppression. Limited fire suppression began in the mid-1970s but has only consisted of one or two four-person hand crews in the summer and fall periods.

The SSPM is located in the southern margin of the North American Mediterranean climate zone (Pyke 1972; Markham 1972; Reyes Coca et al. 1990; Minnich et al. 2000). However, weather data are limited in this area because of its remoteness and the National Observatory of Mexico, which is in the SSPM, has not recorded weather data. A group of temporary weather stations was installed in this range from 1989 to 1992 and average annual precipitation in the upper plateau (Vallecitos Meadow) was $55 \mathrm{~cm}$ (Minnich et al. 2000).

\section{Fire scar sampling}

Fire scar samples were collected from two forest types in the SSPM. One site was located in a Jeffrey pine - mixed conifer forest (site 1) and the other in a Jeffrey pine forest (site 2). The two fire history plots are located at $31^{\circ} 02^{\prime} \mathrm{N}$, $115^{\circ} 27^{\prime} \mathrm{W}$ between 2400 and $2600 \mathrm{~m}$ above sea level and are separated by approximately $1.5 \mathrm{~km}$. Soil parent material is different in the two forest types, granite in the Jeffrey pine mixed conifer forest and quartz shist in the Jeffrey pine forest. Slopes varied between 0 and $25 \%$ and plot aspect was primarily west and southwest. The sampling strategy was to maximize the completeness of an inventory of fire dates within the study site over as a long time period as possible while also collecting samples that were spatially dispersed throughout the study site (Swetnam and Baisan 2002). Sites 1 and 2 were also selected to be within $3 \mathrm{~km}$ of the small park road network to reduce sample hauling distances and were selected to overlap with the study done by Minnich et al. (2000).

To develop an accurate fire history for the last several centuries, full and partial cross sections were cut with a chainsaw from all down logs, snags, and standing trees with at least five externally visible fire scars from each collection site (Arno and Sneck 1977). Each wedge or cross section was sanded and polished to a high sheen (400 grit) so that tree rings and fire scars could be readily distinguished under a microscope. Fire scars were identified by the characteristic disruption and healing patterns of radial tree-ring growth (McBride 1983; Dieterich and Swetnam 1984). The precise year of each fire was determined by cross-dating tree rings in the sections using standard dendrochronological techniques (Stokes and Smiley 1977; Swetnam et al. 1985).
Sample area was approximately $0.8 \mathrm{~km}^{2}$ in both forest types. Sample areas were relatively large in this fire history study because of the goal to determine the number of small versus large fires. Some individual fires will burn an area larger than the sampled areas but many small fires may be contained within them.

The position within the ring in which a scar occurred was noted as EE (early earlywood), ME (middle earlywood), LE (late earlywood), LW (latewood), D (dormant), or U (undetermined) (Caprio and Swetnam 1995) to serve as an estimate of the season of fire occurrence (Ahlstrand 1980; Dieterich and Swetnam 1984). Most specimens were cross-dated by visually comparing them with a nearby chronology (Stokes et al. 1971) obtained from the International Tree-ring Data Bank (Grissino-Mayer and Fritts 1998). The program COFECHA was used to facilitate cross-dating of difficult specimens (Holmes 1983).

As different patterns and properties of ecosystems tend to emerge at different scales (Bissonette 1997), there is probably no single "best" spatial or temporal scale to describe fire regime characteristics. Indeed, wide ranges of fire behavior and effects are common even within individual fires. Therefore, we chose to analyze FRIs at several scales. First, mean and median FRIs were developed for each tree as a point in the landscape (Taylor 2000). However, composite fire chronologies of multiple trees have been found to provide a more comprehensive record of past fires for the site in question (Dieterich 1980; Agee 1993). Composite fire chronologies were developed for multiple scales: $\mathrm{C} 01$, all fires for each site; $\mathrm{C} 02$, fires that scarred at least two trees; $\mathrm{C} 10$, fires that scarred at least two trees and $10 \%$ of the available recording trees; C25, fires that scarred at least three trees and 25\% of available recording trees. $\mathrm{C} 01$ should have the shortest FRIs since even small fires recorded by single trees are included, whereas C25 should have the longest FRIs, since this composite represents fires that scarred many trees over larger areas and are usually less common. $\mathrm{C} 02$ and $\mathrm{C} 10$ are thought to represent fires of intermediate size and severity.

The program SSIZ (Holmes 1995) was used to assess the adequacy of sampling intensity and determine a cutoff date for the composite fire chronologies to reduce interpretation errors that may occur from too few fire-scarred specimens early in the record. This is similar in concept to the use of a species-area curve by botanists to determine adequacy of sample intensity. SSIZ computes an estimated mean number of fires and confidence intervals for different-sized, randomly selected subsets of sampled trees using a Monte Carlo approach (Swetnam and Baisan 2002). The curve flattens when increasing the number of samples in the randomly selected subsets no longer increases the number of fire dates discovered. We assessed the sufficiency of sample intensity for the entire period covered by the fire scar record as well as for each century individually.

For each level of compositing, we determined the median, mean, minimum, and maximum FRI for each site. The Student $t$ test was then used to determine if significant differences $(p<0.05)$ existed in the mean fire interval (MFI) and the Kolmogorov-Smirnov test was used to determine if significant differences $(p<0.05)$ occurred in the fire interval distributions between the two fire history plots (GrissinoMayer 2001). 
Fig. 1. Historical fire activity of site 1 (Jeffrey pine - mixed conifer forest) and site 2 (Jeffrey pine forest) in the Sierra San Pedro Martir, Baja California, Mexico. Each horizontal line is an individual tree and each vertical dash is a dated fire scar.

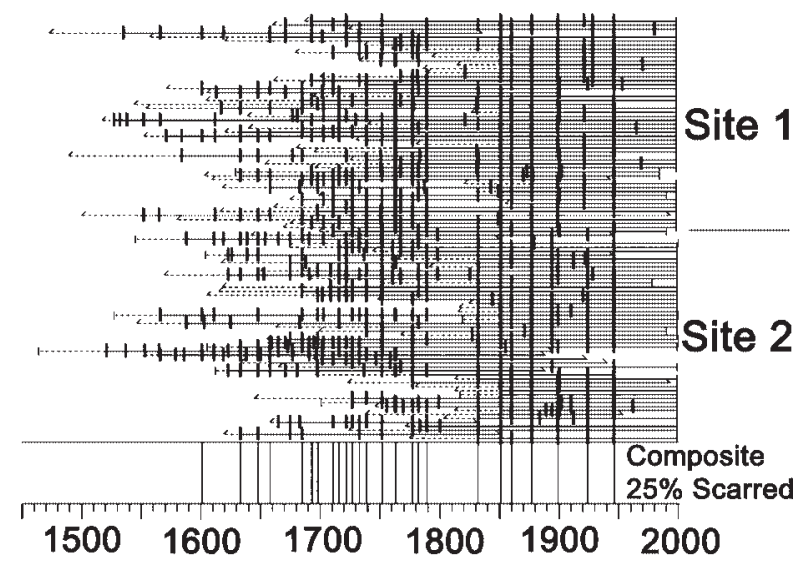

Fire-climate associations were investigated with superposed epoch analysis (Baisan and Swetnam 1995; Grissino-Mayer and Swetnam 2000). Fire occurrence was compared with proxy climate indices reconstructed from tree rings to determine if climate was significantly different from average during, immediately before, and after fire years ( \pm 3 years). For proxy climate indices, we used reconstructed Palmer drought severity index Grid 43 for northern Mexico (PDSI43) and Grid 24 for southern California (Cook 2000a) and the southwestern U.S.A. drought index (Cook 2000b).

\section{Results}

\section{Fire scar analysis}

The majority of fire scar specimens were taken from live Jeffrey pine trees $(76 \%)$, with fewer taken from sugar pine, white fir, snags, and down logs. Since the SSPM has not experienced forest harvesting, no stumps were available. Missing rings occurred on most specimens and specific years were predictable as a subset of those indicated as very narrow rings by the San Pedro Martir chronology (Stokes et al. 1971). Additionally, ring width patterns for most specimens followed the San Pedro Martir chronology very closely, thus facilitating cross-dating.

One hundred and five fire years were identified from 1034 cross-dated fire scars in 105 specimens from the two SSPM fire history plots. Fires were recorded between 1521 and 1980 , but the length of record was different for the two sites. Sixty-seven fires scarred 53 specimens between 1527 and 1980 on site 1 and 86 fires scarred 52 specimens between 1521 and 1962 on site 2 . Twenty-six (39\%) fires in site 1 and $38(44 \%)$ fires in site 2 were detected only on single trees; however, in 12 years, fires were detected on both sites.

\section{FRIs}

Fires were found to have been frequent during the period of record (Fig. 1; Table 1). Although fire scars were dated back to 1521, the number of fire scarred specimens drops off rapidly before 1700 at site 1 and 1650 at site 2 . We selected 1700 as the cutoff date for composites based on visual inspection of Fig. 1 and output from program SSIZ (Fig. 2),
Table 1. Fire interval statistics by century for each site.

\begin{tabular}{|c|c|c|c|c|c|c|}
\hline \multirow[b]{2}{*}{$\begin{array}{l}\text { Composite } \\
\text { scale }\end{array}$} & \multirow[b]{2}{*}{$\begin{array}{l}N \\
\text { intervals }\end{array}$} & \multirow[b]{2}{*}{ Mean } & \multirow[b]{2}{*}{ Min. } & \multirow[b]{2}{*}{ Max. } & \multicolumn{2}{|l|}{$\underline{p}$} \\
\hline & & & & & $1700 \mathrm{~s}$ & $1800 \mathrm{~s}$ \\
\hline \multicolumn{7}{|l|}{ Site 1} \\
\hline \multicolumn{7}{|l|}{$\mathrm{C} 01$} \\
\hline $1700 \mathrm{~s}$ & 21 & 5.9 & 1 & 12 & & \\
\hline $1800 \mathrm{~s}$ & 12 & 9.2 & 1 & 32 & 0.284 & \\
\hline $1900 \mathrm{~s}$ & 10 & 8 & 1 & 19 & 0.121 & 0.738 \\
\hline \multicolumn{7}{|l|}{$\mathrm{C} 02$} \\
\hline $1700 \mathrm{~s}$ & 15 & 5.8 & 1 & 12 & & \\
\hline $1800 \mathrm{~s}$ & 7 & 11.1 & 9 & 43 & 0.587 & \\
\hline $1900 \mathrm{~s}$ & 4 & 15.3 & 1 & 12 & $0.039 *$ & 0.348 \\
\hline \multicolumn{7}{|l|}{$\mathrm{C} 10$} \\
\hline $1700 \mathrm{~s}$ & 14 & 6.5 & 1 & 12 & & \\
\hline $1800 \mathrm{~s}$ & 5 & 22 & 9 & 43 & $0.008 * *$ & \\
\hline $1900 \mathrm{~s}$ & 3 & 15.3 & 1 & 21 & $0.038 *$ & 0.825 \\
\hline \multicolumn{7}{|l|}{$\mathrm{C} 25$} \\
\hline $1700 \mathrm{~s}$ & 9 & 9.6 & 5 & 14 & & \\
\hline $1800 \mathrm{~s}$ & 5 & 22 & 9 & 43 & $0.028 *$ & \\
\hline $1900 \mathrm{~s}$ & 1 & 14.5 & 7 & 22 & & \\
\hline \multicolumn{7}{|l|}{ Site 2} \\
\hline \multicolumn{7}{|l|}{$\mathrm{C} 01$} \\
\hline $1700 \mathrm{~s}$ & 27 & 3.9 & 1 & 9 & & \\
\hline $1800 \mathrm{~s}$ & 17 & 6 & 1 & 25 & 0.079 & \\
\hline $1900 \mathrm{~s}$ & 10 & 6.3 & 1 & 18 & 0.210 & 0.880 \\
\hline \multicolumn{7}{|l|}{$\mathrm{C} 02$} \\
\hline $1700 \mathrm{~s}$ & 19 & 5.3 & 1 & 13 & & \\
\hline $1800 \mathrm{~s}$ & 7 & 9.9 & 1 & 34 & 0.085 & \\
\hline $1900 \mathrm{~s}$ & 5 & 9.4 & 1 & 22 & 0.094 & 0.973 \\
\hline \multicolumn{7}{|l|}{$\mathrm{C} 10$} \\
\hline $1700 \mathrm{~s}$ & 16 & 5.7 & 1 & 13 & & \\
\hline $1800 \mathrm{~s}$ & 5 & 13.4 & 5 & 43 & $0.014 *$ & \\
\hline $1900 \mathrm{~s}$ & 2 & 23.5 & 22 & 25 & & \\
\hline \multicolumn{7}{|l|}{$\mathrm{C} 25$} \\
\hline $1700 \mathrm{~s}$ & 9 & 10.1 & 5 & 25 & & \\
\hline $1800 \mathrm{~s}$ & 5 & 13.4 & 5 & 43 & 0.192 & \\
\hline $1900 \mathrm{~s}$ & 2 & 23.5 & 22 & 25 & & \\
\hline
\end{tabular}

Note: C01, composite of all fire scars; C02, composite of fires scarring two or more trees; $\mathrm{C} 10$, composite of fires scarring two or more trees and at least $10 \%$ of available recording trees; $\mathrm{C} 25$, composite of fires scarring three or more trees and at least $25 \%$ of available recording trees; $p$, probability of the differences in the means between centuries for each scale being due to chance using a two-tailed $t$ test. *, $p<0.05$; **, $p<$ 0.01 .

although the number of samples required varied by century (Fig. 3). FRIs were not significantly different between the two sites at any of the composite scales. Mean and median FRIs varied depending on the composite scale selected and number of trees required to be scarred before the fire is recorded in the composite fire summary. However, median FRIs were shorter than 15 years (majority less than 10 years) for all composite scales, and years between fires varied from 1 and 43 years on individual trees (Table 2). The current fire-free interval is unusually long $(p<0.001)$ at all composite scales with the exception of scale $\mathrm{C} 01$ on site $1(p>$ 0.05) (Table 2). Median FRIs in the forests of the SSPM are similar to those in forests dominated by similar species in the eastern Sierra Nevada, California (Stephens 2001). 
Table 2. Fire return interval data for the entire period of record for each site.

\begin{tabular}{llccccccc}
\hline $\begin{array}{l}\text { Composite } \\
\text { scale }\end{array}$ & $N$ intervals & Median & Mean & Min. & Max. & Current & $p$ & Last fire \\
\hline Site 1 & & & & & & & & \\
C01 & 66 & 5 & 6.9 & 1 & 32 & 18 & $<0.10$ & 1980 \\
C02 & 40 & 8 & 9.9 & 1 & 32 & 52 & $<0.001$ & 1946 \\
C10 & 35 & 9 & 11.3 & 1 & 43 & 52 & $<0.001$ & 1946 \\
C25 & 27 & 13 & 14.5 & 5 & 43 & 52 & $<0.001$ & 1946 \\
Site 2 & & & & & & & & \\
C01 & 70 & 5 & 5.7 & 1 & 25 & 37 & $<0.001$ & 1962 \\
C02 & 34 & 7 & 9.5 & 1 & 43 & 53 & $<0.001$ & 1946 \\
C10 & 31 & 7 & 10.4 & 2 & 43 & 53 & $<0.001$ & 1946 \\
C25 & 24 & 10.5 & 13.0 & 4 & 43 & 53 & $<0.001$ & 1946 \\
\hline
\end{tabular}

Note: C01, composite of all fire scars; C02, composite of fires scarring two or more trees; C10, composite of fires scarring two or more trees and at least $10 \%$ of available recording trees; $\mathrm{C} 25$, composite of fires scarring three or more trees and at least $25 \%$ of available recording trees; $p$, probability of an interval as long as the current interval based on the Weibull distribution of past fire return interval data for each scale.

Fig. 2. Effect of number of fire-scarred specimens on number of fire years discovered in the Sierra San Pedro Martir.
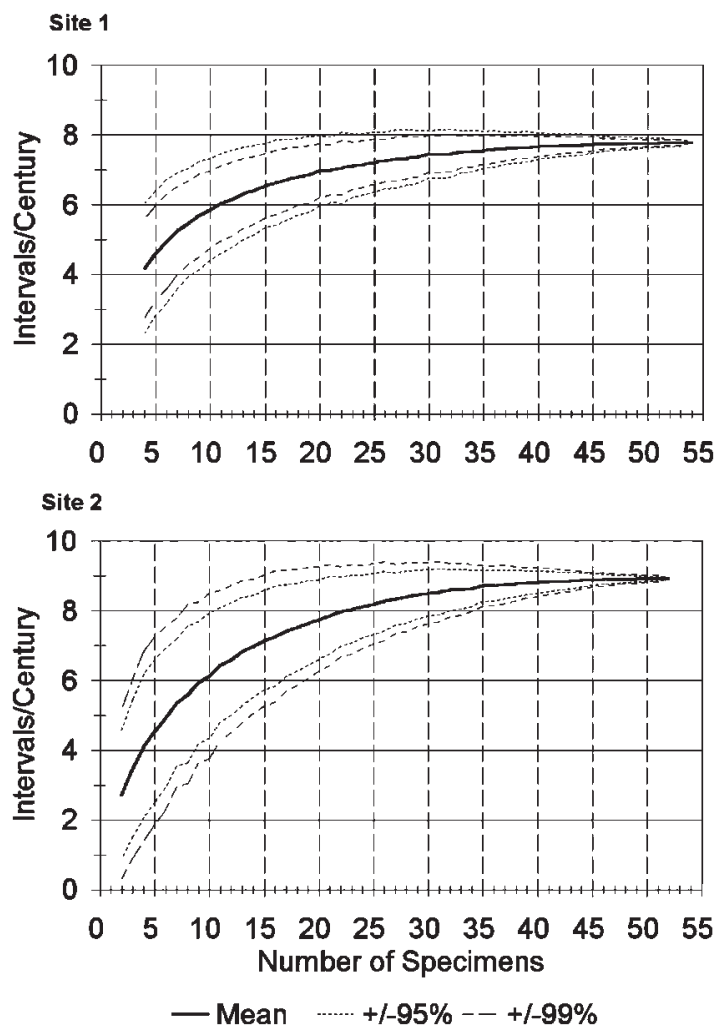

A discontinuity in the fire scar record is apparent during the early 19th century at each site (Fig. 1). FRIs appear to be generally shorter before the discontinuity than afterwards. To test for differences between the two periods and between each century at each level of compositing, we determined the median, mean, minimum, and maximum FRI for each site for the different periods. For each fire, we determined the proportion of specimens scarred at each site (Fig. 4). The Student $t$ test was then used to determine if significant differences $(p<0.05)$ existed in the MFI and the KolmogorovSmirnov test was used to determine if significant differences
Fig. 3. Effect of number of fire-scarred specimens on number of fire years discovered by century in the Sierra San Pedro Martir.
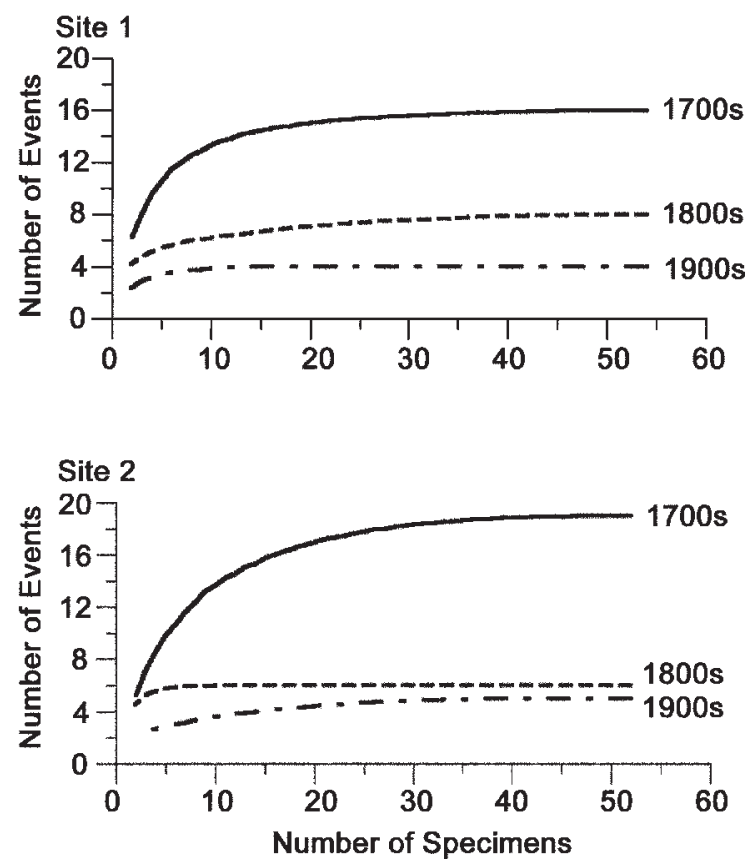

$(p<0.05)$ occurred in the distributions of proportion of trees scarred between the periods. The differences in FRIs were statistically significant for composite scales C02, C10, and $\mathrm{C} 25$ at site 1 and $\mathrm{C} 10$ at site 2 (Table 1). The proportion of trees scarred in the fires of the 1700 s was significantly different from that in the fires of either the 1800s $(p=0.037)$, the 1900s ( $p=0.002)$, or the combined post-1800 period $(p=0.003)$. There was no statistical difference between the proportion of specimens scarred in the 1800 s compared with the 1900s $(p=0.625)$.

The grand mean FRI for single trees (point) was 24.4 years (median, 22.5 years; range of means, 12.4-54.7 years; $\mathrm{SD}, 7.9$ ). The mean number of fire scars on a tree was 9.8 (range, 5-21 years; SD, 4.1 years). The mean age of trees sampled was 302.5 years (range, 144-494 years; SD, 82.8). 
Fig. 4. Percentage of specimens scarred in each fire year by century for each site in the Sierra San Pedro Martir.
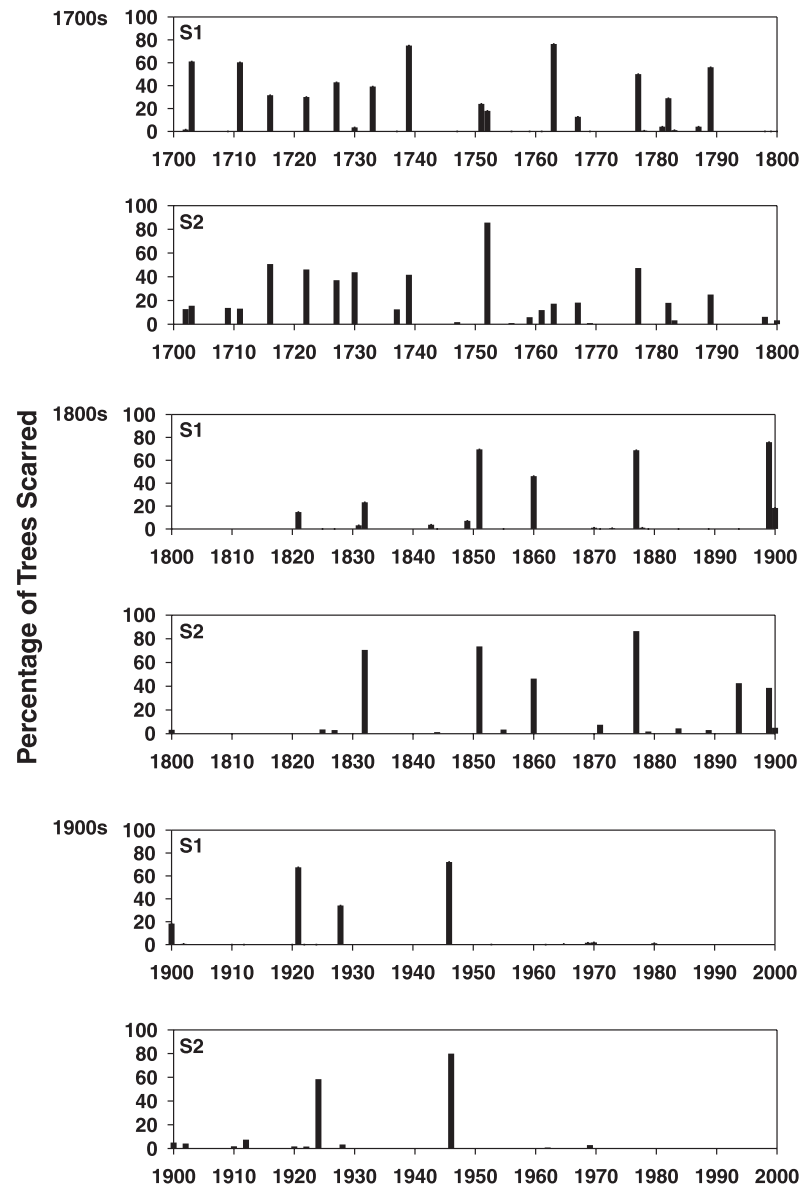

\section{Season of fire}

Intraannual ring position of the scars was determined for $416(82 \%)$ scars on site 1 and $369(72 \%)$ scars on site 2 . It is notable that only four scars $(0.5 \%)$ from the study occurred at the ring boundary that would be associated with dormant season fires. Of the scars in which season could be determined, 91\% were located in the earlywood (EE, ME, and LE positions) of the annual growth rings (Table 3 ). The proportion of fire scars classified in earlywood positions is high through the centuries. However, there is considerable variation by century in the proportions assigned to specific positions with a general decline from $58 \%$ in the 1700 s to $39 \%$ in the 1900s of fires in the EE ring position (Fig. 5).

\section{Fire-climate associations}

Fires that scared more than $10 \%$ of trees in the study sites occurred during years of low precipitation (PDSI43, $p<$ 0.01 ; southwestern U.S.A. drought index, $p<0.01$ ), and the 2 years preceding the fire year were wet (PDSI43: year -1 , $p<0.01$; year $-2, p<0.05$ ) (Fig. 6). Years in which fires scarred less than $10 \%$ of sampled trees or in which no fire was detected showed no association with the precipitation indices.

As the three indices show similar patterns in the fireclimate association, only PDSI43 (the strongest association) will be discussed in detail. Before 1800, the year of the fire
Table 3. Position of fire scars within annual growth rings from fire-scar specimens for each site.

\begin{tabular}{lccccc}
\hline & Site 1 & & Site 2 \\
\cline { 2 - 3 } \cline { 5 - 6 } Season & $N$ & $\begin{array}{c}\text { \% of total } \\
\text { with season }\end{array}$ & & \% of total \\
\hline D & 4 & 1.0 & 0 & 0 \\
EE & 175 & 42.1 & 193 & 52.3 \\
ME & 131 & 31.5 & 108 & 29.3 \\
LE & 67 & 16.1 & & 40 & 10.8 \\
LW & 39 & 9.4 & 28 & 7.6 \\
U & 107 & & 142 & \\
Total & 523 & & 511 & \\
\hline
\end{tabular}

Note: D, dormant; EE, early earlywood; ME, middle earlywood; LE, late earlywood; LW, latewood; U, undetermined.

Fig. 5. Percentage of fire scar intraring positions by century in the Sierra San Pedro Martir. LW, latewood; LE, late earlywood; ME, middle earlywood; EE, early earlywood.
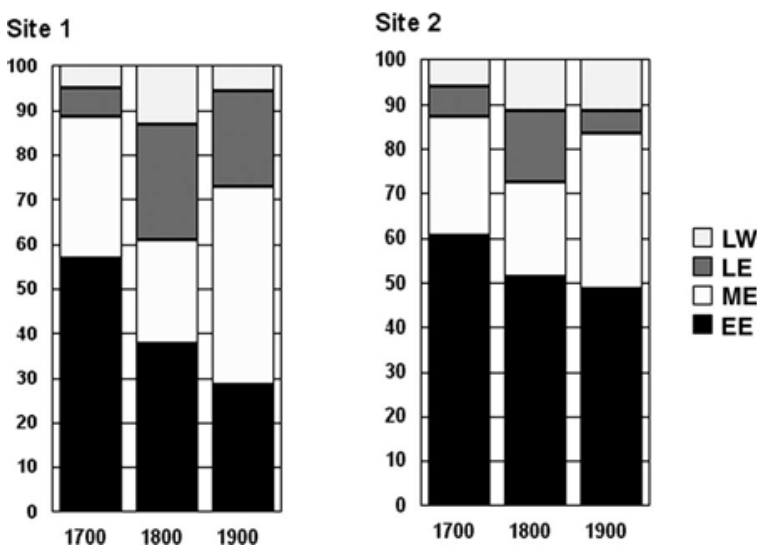

was a significantly dry year $(p<0.01)$ with the preceding year wet $(p<0.01)$ (Fig. 7). After 1800, although the year of the fire still appears dry and the 2 years preceding wet, only year -2 (wet, $p<0.05$ ) was significantly associated with the PDSI43.

\section{Discussion}

The SSPM is unique within the California floristic province in that this large forested area has not been affected by logging or systematic fire suppression. However, it is obvious from Figs. 1 and 4 that the latter part of the 20th century is not representative of earlier periods, especially before 1800 . Indeed, the current fire-free interval is either the longest or one of the longest in the entire record depending on the composite scale chosen (Table 2). In the following sections, we will explore the possible explanations of why the SSPM fire regime changed around 1800 .

We hypothesize that there are three potential causes of the apparent change in the fire regime that began with the long disruption of fire occurrence at the end of the 18th century. (i) The San Pedro Martir Mission was established in 1794 and was briefly occupied through 1806. During this period, livestock grazing was introduced into the SSPM (Meigs 1935; Foster 1991). The introduction of livestock grazing, with its impact on the herbaceous fuel layer, has been associated 
Fig. 6. Superposed epoch analysis of fires scarring more than $10 \%$ of specimens compared with three proxy climate indices. PDSI, Palmer drought severity index.

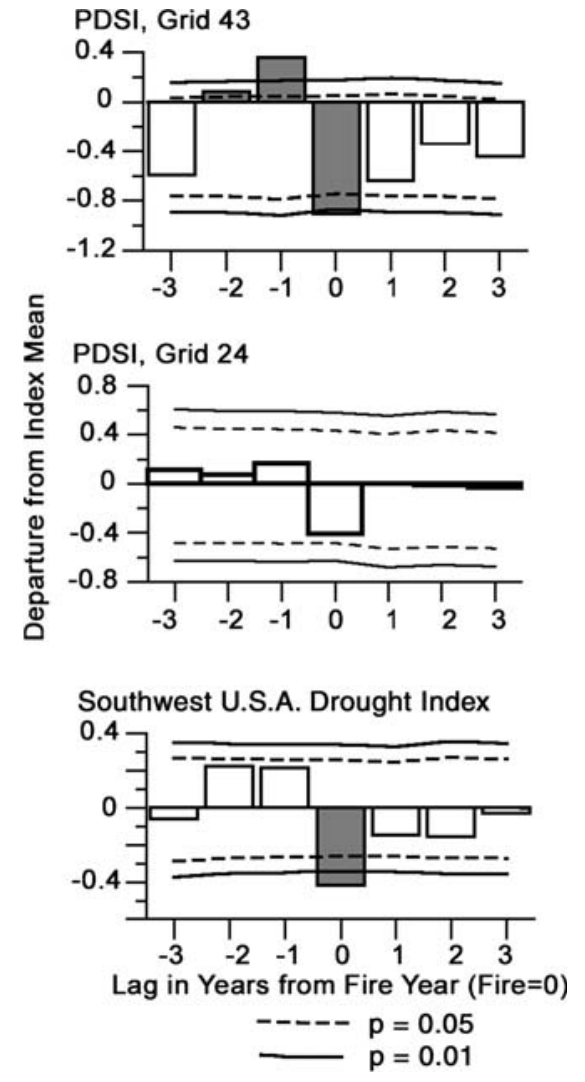

with changes in fire regimes in other areas of western North America (Savage and Swetnam 1990; Touchan et al. 1995). (ii) Major declines in native populations (e.g., Aschmann 1959; Cook 1971) and accompanying disruptions of native land-use patterns have been generally associated with European settlement and are associated with changes in fire frequency and occurrence (Kilgore and Taylor 1979; Carpio and Swetnam 1995). (iii) Changes in regional climate have been noted in other parts of the southwestern United States and northern Mexico (Swetnam and Betancourt 1998; Grissino-Mayer and Swetnam 2000; Kitzberger et al. 2001).

\section{Grazing}

The San Pedro Martir Mission was unique among the California mission system in that it relied more on livestock for sustenance than on crops (Meigs 1935; Foster 1991). The number of livestock in the SSPM was described as "well up to the average mission herd" and in 1801 consisted of 700 cattle, 500 sheep, 150 goats, 50 swine, and 169 horses, mules, and donkeys (Meigs 1935). In 1800, the herd was reported to have 100 fewer cattle, 100 fewer sheep, 30 fewer horses, and 150 more goats and most were located near meadows.

In 1796 , the mission herds were reportedly using several large meadows of the SSPM including La Encantada, which is approximately $10 \mathrm{~km}$ north of the mission site (Arrillaga 1796, referenced by Meigs 1935). Other probable meadows used during this time include La Grulla, Santa Rosa, and Santo Tomas (Meigs 1935). Not mentioned for livestock use
Fig. 7. Superposed epoch analysis of fires scarring more than $10 \%$ of specimens compared with Palmer drought severity index Grid 43 (Cook 2000a) for northern Mexico.

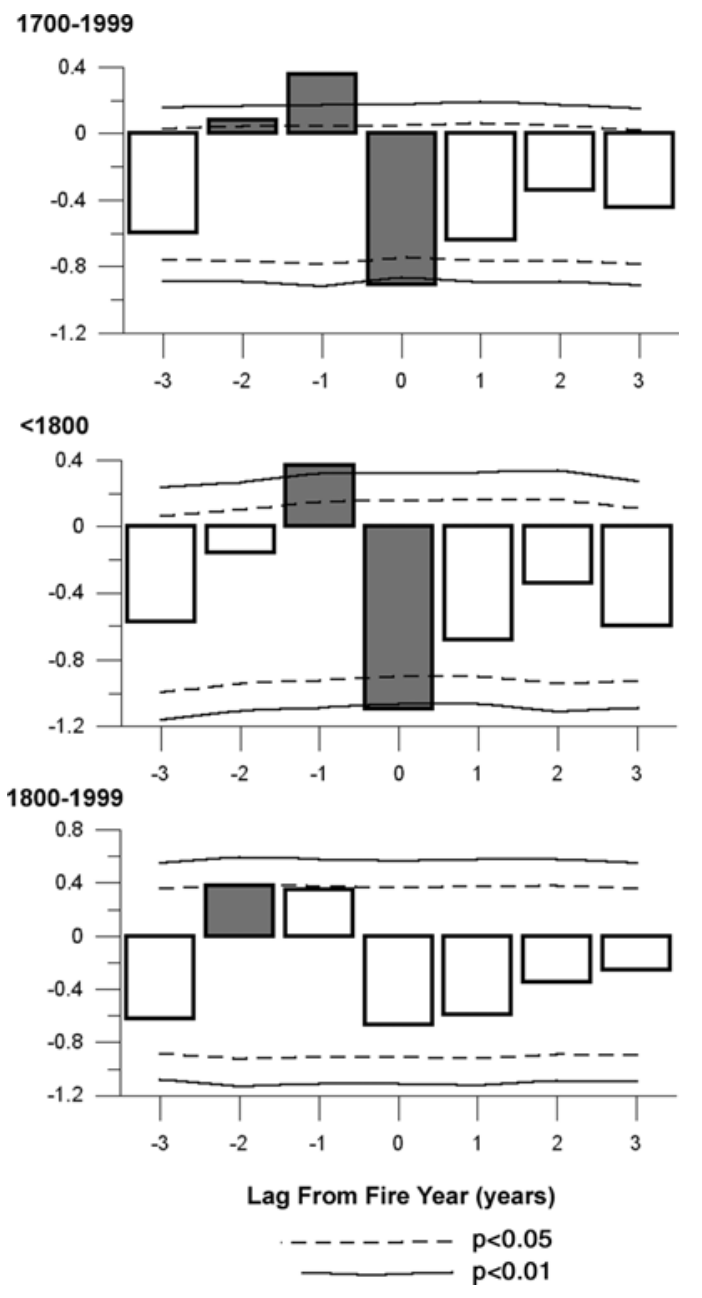

during this period was Vallecitos meadow, which is located on the upper plateau, approximately $24 \mathrm{~km}$ north of the mission site. Vallecitos meadow is also within $3 \mathrm{~km}$ of both of the fire history plots analyzed in this paper. In the mid19th century, cattle numbers increased substantially in the region (Lower Californian newspaper, December 26, 1890; Henderson 1964).

Sheep were important grazers from 1915 through 1964 after which they were denied entry to the national park. The removal of sheep brought about a resurgence of cattle grazing that continues to the present (Meling 1991), and other Mexican sites have documented changes in fire regimes in the middle to late 20th century that were partially explained by ejido reforms (Heyerdahl and Alvardo 2002; Fule and Covington 1999). Although all indications are that herds were small until the middle to late 1800s, the introduction of grazing may have affected fuel continuity due to the low productivity of the area. Indeed, with the exception of the meadows, the study area supports little herbaceous fuel today. The superposed epoch analysis indicated that fires followed wet years, especially before 1800 (Fig. 7). After 1800, the year before fire was not significantly wetter, but 2 years before fire, there was a significant correlation with slightly 
higher precipitation. Climate change and livestock grazing probably reduced the amount of understory vegetation after 1800 in this area.

Reduction of the light grass fuels could affect the size distribution of wildland fires in the SSPM. Herbaceous fuels would have low moisture content in the dry season; in contrast, woody and litter fuels would require more time to dry to low moisture levels. Herbaceous fuels could burn in environmental conditions that would prevent fire spread in woody or litter fuels. Fires ignited in an afternoon thunderstorm could burn through dry herbaceous fuels, but as temperature dropped and relative humidity increased in the evening, they could have been extinguished. Removal of the herbaceous fuels would therefore reduce the number of small fires but larger scale fires could continue, since they are commonly correlated with droughts in western North America (Swetnam 1993).

The number of livestock in the SSPM early in the 19th century was low, and therefore, the change in fire regime at this time was probably not influenced by early grazing. In the middle to late 19th century, the number of livestock increased substantially. This increase in livestock density could have substantially reduced the amount of herbaceous fuels in the forest understory and this could have influenced the fire regime.

\section{Native population decline}

The size of the native populations (Paipai and Kiliwa Indians) in the northern and eastern portions of the SSPM before missionary contact was estimated to be 630 people or 0.63 person per square mile (Meigs 1935). This was the lowest population density for any area surrounding a Baja California mission. Estimates of the Nakipa Indian population that includes the western foothills of the SSPM are unknown, and therefore, the above population estimates are probably conservative.

According to the Kiliwa in 1926, the forest-covered SSPM plateau was never permanently inhabited by Indians because of the winter cold (Meigs 1935). The plateau slopes were visited annually for pinion pine (Pinus monophylla Torr. \& Frém.) seeds and the forests were used as an area to hunt deer in the summer. There is no historical record of the native peoples using fire in the forests of the SSPM, although they did use it in the scrublands below the mountains to hunt rabbits (Meigs 1935).

Native populations dropped quickly after European contact in Baja California, and this was the fundamental cause for the deterioration of the missions (Meigs 1935; Aschmann 1959). Diseases included severe epidemics of smallpox, syphilis, and other ailments (Meigs 1935).

The native peoples of other areas of northern Baja California are reported to have commonly used fire to manage for necessary vegetative resources (Bean and Lawton 1993). The Spanish are known to have discouraged the use of fire (see Barrett $1935^{2}$ ) because of the immediate reduction in available forage for horses and grazing animals. If the people of the SSPM originally used fire, as did other peoples of
Baja California, then their decline and cultural disruption are likely to have influenced the fire regime.

\section{Climate variation}

The period of reduced fire occurrence in the SSPM from approximately the 1790 s to 1830 s coincides with a period of reduced fire occurrence at many sites in the southwestern United States, northern Mexico, and southern South America (Touchan et al. 1995; Grissino-Mayer and Swetnam 1997, 2000; Swetnam and Betancourt 1998; Kitzberger et al. 2001; Heyerdahl et al. 2002). Following the late 18th - early 19th century transition (LEENT), many sites have experienced less frequent fires with more synchrony between sites (Touchan et al. 1995; Grissino-Mayer and Swetnam 2000; Swetnam et al. 2001). Our two sites from the SSPM follow a similar pattern of fewer fires with a high proportion of sample trees being scarred in each fire after LEENT (Figs. 1 and 4).

Kitzberger et al. (2001) found the reduction in fire occurrence to have occurred during a decline in the frequency and amplitude of the El Niño - Southern Oscillation. That similar changes took place coincidentally in both North and South America suggests that climate is a likely contributor. Further evidence that climate may have been the main process in the development of LEENT is found in isolated ponderosa pine forests in New Mexico. These forests have never experienced logging, fire suppression, or livestock grazing but LEENT is still present beginning in the early 1800 s (Touchan et al. 1995; Grissino-Mayer and Swetnam 1997).

It appears that climatic variation played an important role in initiation and possible maintenance of the changes in fire frequency in the SSPM. However, the coincident timing of changes in cultural practices, particularly the possible reduction of fire use by native peoples, is likely to have contributed to fire regime changes. Higher grazing intensities in the late 19 th century could have influenced the size distribution of fires. Additional work will be necessary to segregate the degree of influence of each potential factor.

\section{Fire history reconstruction: aerial photographs compared with tree rings}

There are advantages and disadvantages of dendrochronology and aerial photograph based methods of fire history analysis. Fire histories that use information from air photographs or satellites are limited to a period of less than 80 years and to the frequency in which photographs or images were acquired. Where fires are generally frequent and of low intensity, the frequency of photograph acquisition may not be sufficient to detect many low-severity fires occurring between acquisitions. However, this type of analysis provides additional evidence for detecting and linking changes in pattern and ecosystem structure to past fires (Taylor and Skinner 1998), something that is difficult to do with fire histories that are based solely on the analysis of tree rings (Stephens and Elliot-Fisk 1998). An additional advantage of this type of analysis is the potential to assess data of high spatial resolution at very broad spatial scales.

Fire histories based on the analysis of fire scars have the advantage of producing long records of high temporal reso-

\footnotetext{
${ }^{2}$ L.A. Barrett. 1935. A record of forest and field fires in California from the days of the early explorers to the creation of the forest reserves. Unpublished report to the Regional Forester. Available at the Bancroft Library, University of California, Berkeley, Calif.
} 
Fig. 8. Specimens scarred in 1899 and 1 year later in 1900 from site 1 in the Sierra San Pedro Martir.

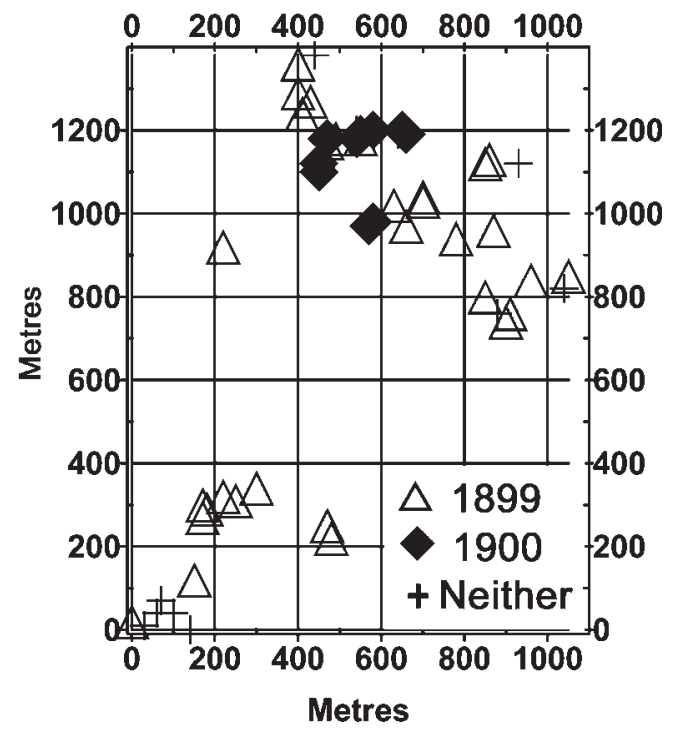

lution and precision. Many studies in the western United States have been able to document past fire occurrence over the last 300-400 years (Heyerdahl et al. 1995; Skinner and Chang 1996). Past fires can be precisely dated to the year when using cross-dating techniques (Stokes and Smiley 1977). Additionally, the season of past fires can be estimated (Ahlstrand 1980; Dieterich and Swetnam 1984). A drawback of tree-ring analyses is that they are labor intensive and most have been of limited spatial extent or intensity. It is possible to detect and link changes in pattern and ecosystem structure to past fires using fire scars and tree ages, but it does require extensive sampling that can be difficult to implement.

The tree-ring data in this work depict a fire regime similar to that described by Minnich et al. (2000) during the period the studies overlap (1925-1991). During this period, the firescar record indicates that fires were generally of two types: either small, scarring mostly single specimen trees, or large, leaving few specimen trees unscarred (Fig. 4). The large fires were rare during the time of overlap, occurring in 1928 (site 1) and 1946 (both sites). All other fires since 1925 were recorded on single trees with the exception of 1969 recorded on two trees. A large fire occurred in site 2 in 1924 immediately preceding the Minnich et al. (2000) study period. We see no justification for the assertion by Minnich et al. (2000) that fire-scar based fire history studies would tend to overstate the occurrence of fires.

The 52-year fire rotation reported for the Jeffrey pine mixed conifer forests by Minnich et al. (2000) is approximately twice as long as the MFI reported by the most widely spread fires $(\mathrm{C} 25,1900 \mathrm{~s})$ in this work (Table 1). Differences can partially be attributed to the different fire statistics. The fire rotation is the number of years required to burn an area equivalent to the study area. The MFI is a measure of the central tendency of plot-level fire occurrence but is not directly equitable to area burned. Synchronous dates on widely distributed fire-scarred trees can be interpreted to infer the occurrence of relatively widespread fires but not necessarily that all portions of the intervening landscape burned.
Fig. 9. Summer precipitation amounts for the Sierra San Pedro Martir, Arizona, southern California, and the Sierra Nevada within the mixed-conifer and pine forest zones.

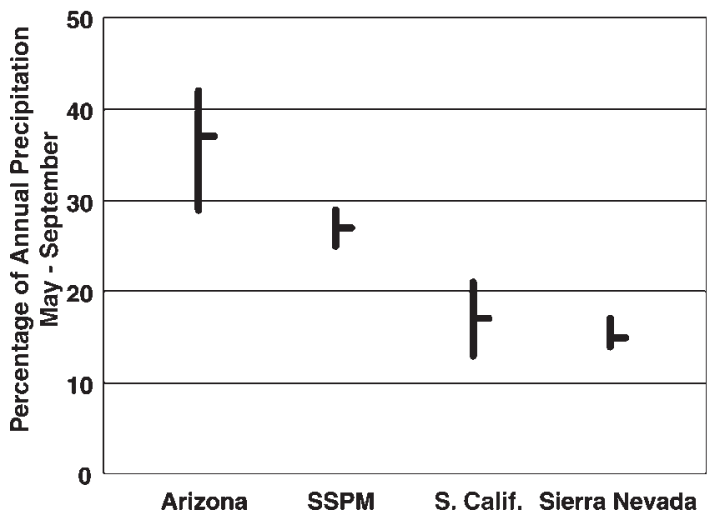

Another problem with the use of a limited number of aerial photographs (five photographs over 60+ years) (Minnich et al. 2000) to determine fire rotation in a low- to moderateseverity fire regime is the potential to miss fires. Aerial photographs commonly bracket a period of years. Without firescar data, it may be difficult or impossible to distinguish between two fires that burned adjacent to each other within a few years. For example, a large fire burned much of site 1 in 1899. The following year, another fire burned part of the site (Fig. 8). It would be difficult to determine that these were separate fires from aerial photographs taken several years later. However, this could be meaningful ecological information, since the area not burned in 1899 could serve as a refuge for various species of plants and small animals from which to reoccupy the 1899 burned area before the 1900 fire.

There is potential for both methods to work in unison, since data derived from fire scars and aerial photographs can be complimentary. Fire scars can provide specific information to date past fire patterns in aerial photographs. Without this type of information, it would be impossible to precisely date stand patterns when the photograph acquisitions are separated by a number of years.

\section{Differences between Alta California and SSPM fire regimes}

The intraring locations of fire scars are quite different between the western Sierra Nevada, Cascade Range, and Klamath Mountains of California and the SSPM. This indicates a difference in the seasonality of fires.

Fire scars in the Klamath Mountains and the Cascade Range form mostly at the ring boundary and are interpreted there as late summer and early fall (Taylor and Skinner 1998; Taylor 2000; Beaty and Taylor 2001; Bekker and Taylor 2001). Fire scars in the southern Sierra Nevada form mostly in latewood (approximately 10\% earlywood) and are interpreted there as primarily middle to late summer (Swetnam et al. 1992; Caprio and Swetnam 1995). The predominance of fire scars forming in late summer to fall is considered typical of Mediterranean climate regions with fires following the long annual dry period.

Fire scars in the SSPM are primarily located in earlywood, indicating fires of late spring to midsummer. The pre- 
dominance of earlywood scars is similar to that of Arizona, New Mexico, and northern Mexico (Grissino-Mayer and Swetnam 2000; Swetnam et al. 2001; Heyerdahl and Alvarado 2002). This pattern is considered typical of fire regimes in the dry spring - early summers of the summer monsoon climate of northern Mexico and the southwestern United States. In this climate, fires are inhibited in the latter part of the warm season due to monsoon rains.

We investigated the annual precipitation patterns of the $\mathrm{Si}$ erra Nevada, southern California, Arizona, and the SSPM. It appears that the SSPM is transitional between the California Mediterranean climate and the southwestern North American monsoon climate (Fig. 9). The subtle increase in proportion of annual rainfall occurring in the warm season in the SSPM appears sufficient to change the predominant season of fire occurrence.

\section{Conclusion}

If recent (1970 to present) fire suppression activities are maintained or expanded in the SSPM, this will likely result in increased fire hazards and associated problems with forest sustainability. The Sierra Nevada presently has over $1 \times$ $10^{6}$ ha of pine-dominated forests that have very high fire hazards (U.S. Department of Agriculture 2001). The managers of the SSPM National Park should allow lightning-ignited fires to burn, but those ignited near the national observatory could be suppressed to maintain clear skies for the observatory. A system of management-ignited prescribed fires timed to occur 1-2 weeks before the summer monsoon could be used in the areas near the observatory. This could produce a sustainable forest ecosystem and reduce the impacts of smoke production on the observatory.

Global climate change may produce large changes in California's ecosystems (Fields et al. 1999) including more summer precipitation. This may have a pronounced effect on California's fire regimes because only a slight increase in summer precipitation may shift the majority of fires from the dormant to active growing season. The effects of the change would probably be significant, since fires at different seasons can produce quite different effects (Harrington 1987; Howe 1994). More information about the distribution of precipitation under a changing climate is needed (Dale et al. 2000), but forests with similar floristic compositions subjected to slightly higher amounts of summer precipitation in the SSPM have a significantly different fire season when compared with the western slope of the Sierra Nevada and Klamath Mountains.

The SSPM is unique within the California floristic province in that this large forested area has not been affected by logging or systematic fire suppression. While the SSPM and many California forests share many similar attributes, the SSPM is unlikely to be a "pristine" surrogate for the western Sierra Nevada or Klamath Mountains. Fire regimes of the southern California mountains and eastern Sierra Nevada are poorly understood and may be more similar to that found in the SSPM.

\section{Acknowledgments}

We sincerely thank Dr. Ernesto Franco Vizcaíno, Institute for Earth Systems Science and Policy, California State
University, Monterey Bay, and Departamento de Ecología Centro de Investigación Científica y de Educación Superior de Ensenada (CICESE), Ensenada, Baja California, Mexico, for his support during this work. We also thank Ken Herman, Bret Sampson, Celeste Abbott, Terese Kastner, Gary Roller, Glen Everest, Richard Haight, Horacio de la Cueva, and Jason Kirschenstein for field and laboratory assistance. The senior author thanks Pat Shea for introducing him to the SSPM. This project was supported by USDA Agricultural Experiment Station funds from the University of California, Berkeley, and California Polytechnic State University, San Luis Obispo.

\section{References}

Agee, J.K. 1993. Fire ecology of pacific northwest forests. Island Press, Washington, D.C.

Ahlstrand, G.M. 1980. Fire history of a mixed conifer forest in Guadalupe Mountains National Park. In Proceedings of the Fire History Workshop, 20-24 Oct. 1980, Tucson, Ariz. Technical Coordinators: M.A. Stokes and J.H. Dieterich. U.S. For. Serv. Gen. Tech. Rep. RM-81. pp. 4-7.

Arno, S.F., and Sneck, K.M. 1977. A method for determining fire history in coniferous forests of the mountain west. U.S. For. Serv. Gen. Tech. Rep. INT-42.

Aschmann, H.H. 1959. The central desert of Baja California: demography and ecology. University of California Press, Berkeley, Calif.

Baisan, C.H., and Swetnam, T.W. 1995. Historical fire occurrence in remote mountains of southwestern New Mexico and northern Mexico. In Proceedings of the Symposium on Fire in Wilderness and Park Management, 30 Mar. - 1 Apr. 1993, Missoula, Mont. Technical Coordinators: J.K. Brown, R.W. Mutch, C.W. Spoon, and R.H. Wakimoto. U.S. For. Serv. Gen. Tech. Rep. INT-GTR-320. pp. 153-156.

Baker, W.L., and Ehle, D. 2001. Uncertainty in surface-fire history: the case of ponderosa pine forests in the western United States. Can. J. For. Res. 31: 1205-1226.

Bean, L.J., and Lawton, H.W. 1993. Some explanations for the rise of cultural complexity in Native California with comments on proto-agriculture and agriculture. In Before the wilderness: environmental management by native Californians. Edited by T.C. Blackburn and K. Anderson. Ballena Press, Menlo Park, Calif. Anthropol. Pap. 40. pp. 27-54.

Beaty, R.M., and Taylor, A.H. 2001. Spatial and temporal variation of fire regimes in a mixed conifer forest landscape, southern Cascades, California, USA. J. Biogeogr. 28: 955-966.

Bekker, M.F., and Taylor, A.H. 2001. Gradient analysis of fire regimes in montane forests of the southern Cascade Range, Thousand Lakes Wilderness, California, USA. Plant Ecol. 155: 15-28.

Bissonette, J.A. 1997. Scale-sensitive ecological properties: historical context, current meaning. In Wildlife and landscape ecology: effect of pattern and scale. Edited by J.A. Bissonette. Springer, New York. pp. 3-31.

Burns, R.M., and Honkala, B.H. 1990. Silvics of North America. Vol. 1. U.S. Dep. Agric. For. Serv. Agric. Handb. 654.

Caprio, A.C., and Swetnam, T.W. 1995. Historic fire regimes along an elevational gradient on the west slope of the Sierra Nevada, California. In Proceedings of the Symposium on Fire in Wilderness and Park Management, 30 Mar. - 1 Apr. 1993, Missoula, Mont. Technical Coordinators: J.K. Brown, R.W. Mutch, C.W. Spoon, and R.H. Wakimoto. U.S. For. Serv. Gen. Tech. Rep. INT-GTR-320. pp. 8-14. 
Chang, C. 1999. Understanding fire regimes. Ph.D. dissertation, Duke University, Durham, N.C.

Cook, S.F. 1971. Conflict between the California Indian and white civilization. In The California Indians: a source book. 2nd ed. Edited by R.F. Heizer and M.A. Whipple. University of California Press, Berkeley, Calif. pp. 562-571.

Cook, E.R. 2000a. North American drought variability PDSI reconstructions. International Tree-Ring Data Bank. IGBP PAGES/World Data Center-A for Paleoclimatology, Data Contrib. Ser. 2000074. NOAA/NGDC Paleoclimatology Program, Boulder, Colo. Available from http://www.ngdc.noaa.gov/paleo/recons-treering.html [cited 4 May 2001].

Cook, E.R. 2000b. Southwestern USA drought index reconstruction. International Tree-Ring Data Bank. IGBP PAGES/World Data Center-A for Paleoclimatology, Data Contrib. Ser. 2000053. NOAA/NGDC Paleoclimatology Program, Boulder, Colo. Available from http://www.ngdc.noaa.gov/paleo/recons-treering.html [cited 4 May 2001].

Dale, V.H., Joyce, L.A., McNulty, S., and Neilson, R.P. 2000. The interplay between climate change, forests, and disturbances. Sci. Total Environ. 262: 201-204.

Dieterich, J.H. 1980. The composite fire interval - a tool for more accurate interpretations of fire history. In Proceedings of the Fire History Workshop, 20-24 Oct. 1980, Tucson, Ariz. Technical Coordinators: M.A. Stokes and J.H. Dieterich. U.S. For. Serv. Gen. Tech. Rep. RM-81. pp. 8-14.

Dieterich, J.H., and Swetnam, T.W. 1984. Dendrochronology of a fire-scarred ponderosa pine. For. Sci. 30: 238-247.

Field, C.B., Dialy, G.C., Davis, F.W., Gaines, S., Matson, P.A., Melack, J., and Miller, N.L. 1999. Confronting climate change in California: ecological impacts on the golden state. Union of Concerned Scientists, Cambridge, Mass., and the Ecological Society of America, Washington, D.C.

Flannigan, M.D., Stocks, B.J., and Wotton, B.M. 2000. Climate change and forest fires. Sci. Total Environ. 262: 221-229.

Foster, J.W. 1991. The mission San Pedro Martir de Verona: a brief history and assessment of interpretive potential within a biosphere reserve. In Memoirs of the International Conference of the Potential of the Peninsular Range of the California's as a Biosphere Reserve, 18-19 Mar. 1991, Ensenada, Mexico. Edited by E. Franco-Vizcaíno and J. Sosa-Ramírez. Center for Scientific Research and Higher Education of Ensenada (CICESE) CICESE09101, Ensenada, Baja California, Mexico. p. 32.

Fritts, H., and Swetnam, T.W. 1989. Dendroecology: a tool for evaluating variations in past and present forest environments. Adv. Ecol. Res. 19: 111-188.

Fulé, P.Z., and Covington, W.W. 1999. Fire regime changes in La Michilía Biosphere Reserve, Durango, Mexico. Conserv. Biol. 13: $640-652$.

Grissino-Mayer, H.D. 2001. FHX2 - software for analyzing temporal and spatial patterns in fire regimes from tree rings. TreeRing Res. 57: 115-124.

Grissino-Mayer, H.D., and Fritts, H. (Editors). 1998. International Tree-Ring Data Bank. IGBP PAGES/World Data Center-A for Paleoclimatology. NOAA/NGDC Paleoclimatology Program, Boulder Colo. Available from http://www.ngdc.noaa.gov/paleo/ treering.html [cited 4 May 2001].

Grissino-Mayer, H.D., and Swetnam, T.W. 1997. Multi-century history of wildfire in the ponderosa pine forests of El Malpais National Monument. Bull. N.M. Bur. Mines Mineral Resour. 156: $163-172$.

Grissino-Mayer, H.D., and Swetnam, T.W. 2000. Century-scale climate forcing of fire regimes in the American Southwest. Holocene, 10: 213-220.
Habeck, R.J. 1992. Pinus jeffreyi. In U.S. Department of Agriculture, Forest Service, Rocky Mountain Research Station, Fire Sciences Laboratory (2002, April). Fire effects information system. Available from http://www.fs.fed.us/database/feis/ [cited 3 April 2002].

Harrington, M.G. 1987. Ponderosa pine mortality from spring, summer, and fall crown scorching. West. J. Appl. For. 2: 14-16.

Henderson, D.A. 1964. Agriculture and stock raising in Baja California. Ph.D. dissertation, University of California, Los Angeles, Los Angeles, Calif.

Heyerdahl, E.K., and Alvarado, E. 2002. Influence of climate and land use on historical surface fires in pine-oak forests, Sierra Madre Occidental, Mexico. In Fire and climatic change in temperate ecosystems of the western Americas. Edited by T.T. Veblen, W.L. Baker, G. Montenegro, and T.W. Swetnam. Springer-Verlag, New York.

Heyerdahl, E.K., Berry, D., and Agee, J.K. 1995. Fire history database of the western United States. EPA/600/R-96/081. U.S. EPA Environmental Research Laboratory, Corvallis, Oreg.

Heyerdahl, E.K., Brubaker, L.B., and Agee, J.K. 2002. Annual and decadal influence of climate on fire regimes (1687-1994) of the Blue Mountains, USA. Holocene, 12: 597-604.

Holmes, R.L. 1983. Computer-assisted quality control in tree-ring dating and measurement. Tree-Ring Bull. 43: 69-78.

Holmes, R.L. 1995. Effect of sample size on fire frequency estimates: description of computer program SSIZ. Dendrochronology Program Library. Available from http://www.ltrr.arizona.edu/pub/dpl/ [cited 18 April 2001].

Howe, H.F. 1994. Response of early- and late-flowering plants to fire season in experimental prairies. Ecol. Appl. 4: 121-133.

Incropera, F.P., and de Witt, D.P. 1990. Fundamentals of heat and mass transfer. 3rd ed. John Wiley \& Sons, New York.

Keeley, J.E., and Stephenson, N.L. 2000. Restoring natural fire regimes to the Sierra Nevada in an era of global change. In Wilderness Science in a Time of Change Conference. Vol. 5. Wilderness Ecosystems, Threats, and Management, 23-27 May 1999, Missoula, Mont. Compiled by D.N. Cole, S.F. McCool, W.T. Borrie, and J.O. O'Loughlin. Proceedings RMRS-P-15VOL5. USDA Forest Service, Rocky Mountain Research Station, Ogden, Utah. pp. 255-265.

Kilgore, B.M., and Taylor, D. 1979. Fire history of a sequoia mixed conifer forest. Ecology, 60: 129-142.

Kitzberger, T., Swetnam, T.W., and Veblen, T.T. 2001. Interhemispheric synchrony of forest fires and the El Nino - Southern Oscillation. Global Ecol. Biogeogr. 10: 315-326.

Markham, C.B. 1972. Baja California's climate. Weatherwise, 25: 64-76.

McBride, J.R. 1983. Analysis of tree rings and fire scars to establish fire history. Tree-Ring Bull. 43: 51-67.

Meigs, P. 1935. The Dominican missions frontier of Lower California. Univ. Calif. Publ. Geogr. 7: 1-232.

Meling, D. 1991. Raising cattle on the Sierra San Pedro Martir. In Memoirs of the International Conference of the Potential of the Peninsular Range of the California's as a Biosphere Reserve, 18-19 Mar. 1991, Ensenada, Mexico. Edited by E. FrancoVizcaíno and J. Sosa-Ramírez. Center for Scientific Research and Higher Education of Ensenada (CICESE) CICESE09101, Ensenada, Baja California, Mexico. pp. 16-17.

Millar, C.I., and Woolfenden, W.B. 1999. The role of climate change in interpreting historical variability. Ecol. Appl. 9: 12071216.

Minnich, R.A. 1987. The distribution of forest trees in northern Baja California. Madrono, 34: 98-127. 
Minnich, R.A., and Chou, Y.H. 1997. Wildland fire patch dynamics in Californian chaparral of southern California and northern Baja California. Int. J. Wildland Fire, 7: 221-248.

Minnich, R.A., and Franco, E. 1998. Land of chamise and pines: historical accounts and current status of northern Baja California's vegetation. Univ. Calif. Publ. Bot. 80 .

Minnich, R.A., Barbour, M.G., Burk, J.H., and Fernau, R.F. 1995. Sixty years of change in California conifer forests of the San Bernardino Mountains. Conserv. Biol. 9: 902-914.

Minnich, R.A., Franco-Vizcaino, E.F., Sosa-Ramirez, J., Burk, J.H., Barry, W.J., Barbour, M.G., and de la Cueva Salcedo, H. 1997. A land above: protecting Baja California's Sierra San Pedro Martir within a biosphere reserve. J. Southwest, 39: 613-695.

Minnich, R.A., Barbour, M.G., Burk, J.H., and Sosa-Ramirez, J. 2000. Californian mixed-conifer forests under unmanaged fire regimes in the Sierra San Pedro Martir, Baja California, Mexico. J. Biogeogr. 27: 105-129.

Pyke, C.B. 1972. Some meteorological aspects of the seasonal distribution of precipitation in the western United States and Baja California. University of California Water Resources Center, Los Angeles, Calif. Contrib. 139.

Reyes Coca, S., Miranda Reyes, F., and Garcia Lopez, J. 1990. Climatologia de la Region Noroeste de Mexico. Parte I. Precipitacion: series de tiempo del valor total mensual y estadisticas del ano climatologicogico. Grupo de Meteorologia, Centro de Investigación Científica y de Educación Superior de Ensenada (CICESE), Comision Nacional del Agua, Reporte Tecnico CIOFIT9001, Ensenada, Baja California, Mexico.

Russel, W.H., McBride, J.R., and Rowntree, R. 1998. Revegetation after four stand replacing fires in the Lake Tahoe Basin. Madrono, 45: 40-46.

Savage, M. and Swetnam, T.W. 1990. Early and persistent fire decline in a Navajo ponderosa pine forest. Ecology, 70: 23742378.

Skinner, C.N., and Chang, C. 1996. Fire regimes, past and present. In Sierra Nevada Ecosystem Project: final report to Congress. Vol. II. Assessments and scientific basis for management options. Centers for Water and Wildland Resources, University of California, Davis, Calif. Water Resour. Cent. Rep. 37. pp. 10411069.

Stephens, S.L. 2001. Fire history of adjacent Jeffrey pine and upper montane forests in the Eastern Sierra Nevada. Int. J. Wildland Fire, 10: 161-176.

Stephens, S.L., and Elliott-Fisk, D.E. 1998. Sequoiadendron giganteum-mixed conifer forest structure in 1900-1901 from the southern Sierra Nevada, CA. Madrono, 45: 221-230.

Stine, S. 1996. Climate, 1650-1850. In Sierra Nevada Ecosystem Project: final report to Congress. Vol. II. Assessments and scientific basis for management options. Centers for Water and Wildland Resources, University of California, Davis, Calif. Wildland Resour. Cent. Rep. 37. pp. 25-30.

Stokes, M.A., and Smiley, T.L. 1977. An introduction to tree-ring dating. University of Chicago Press, Chicago, Ill.

Stokes, M., Harlan, T., and Clemans, S. 1971. Sierra San Pedro Martir Low: MEXI001.CRN Pinus ponderosa. In International Tree-ring Data Bank. IGBP PAGES/World Data Center-A for
Paleoclimatology. Edited by H. Grissino-Mayer and H. Fritts. NOAA/NGDC Paleoclimatology Program, Boulder, Colo.

Swetnam, T.W. 1993. Fire history and climate change in sequoia groves. Science (Washington, D.C.), 262: 885-889.

Swetnam, T.W., and Baisan, C.H. 2002. Tree-ring reconstructions of fire and climate history in the Sierra Nevada and southwestern United States. In Fire and climatic change in the Americas. Edited by T.T. Veblan, W. Baker, G. Montenegro, and T.W. Swetnam. Springer-Verlag, New York.

Swetnam, T.W., and Betancourt, J.L. 1992. Temporal patterns of El Nino/Southern Oscillation - wildfire patterns in the Southwest United States. In El Nino: historical and paleoclimatic aspects of the Southern Oscillation. Edited by H.F. Diaz and V.M. Markgraf. Cambridge University Press, New York.

Swetnam, T.W., and Betancourt, J.L. 1998. Mesoscale disturbance and ecological response to decadal climatic variability in the American Southwest. J. Clim. 11: 3128-3147.

Swetnam, T.W., Thompson, M.A., and Sutherland, E.K. 1985. Spruce budworm handbook, using dendrochronology to measure radial growth of defoliated trees. U.S. Dep. Agric. Agric. Handb. 639.

Swetnam, T.W., Allen, C.D., and Betancourt, J.L. 1999. Applied historical ecology: using the past to manage the future. Ecol. Appl. 9: 1189-1206.

Swetnam, T.W., Baisan, C.H., Caprio, A.C., Touchan, R., and Brown, P.M. 1992. Tree-ring reconstruction of giant sequoia fire regimes. Final report to Sequoia, Kings Canyon and Yosemite National Parks, Cooperative Agreement No. DOI 8018-1-1002. Laboratory of Tree Ring Research, University of Arizona, Tucson, Ariz.

Swetnam, T.W., Baisan, C.H., and Kaib, J.M. 2001. Forest fire histories of the sky islands of La Frontera. In Changing plant life of La Frontera: observations on vegetation in the United States/Mexico borderlands. Edited by G.L. Webster and C.J. Bahre. University of New Mexico Press, Albuquerque, N.M. pp. 95-123.

Taylor, A.H. 2000. Fire regimes and forest changes along a montane forest gradient, Lassen Volcanic National Park, southern Cascade Mountains, USA. J. Biogeogr. 27: 87-104.

Taylor, A.H., and Skinner, C.N. 1998. Fire history and landscape dynamics in a late-successional reserve, Klamath Mountains, California, USA. For. Ecol. Manage. 111: 285-301.

Touchan, R., Swetnam, T.W., and Grissino-Mayer, H.D. 1995. Effects of livestock grazing on pre-settlement fire regimes in New Mexico. In Proceedings of the Symposium on Fire in Wilderness and Park Management, 30 Mar. - 1 Apr. 1993, Missoula, Mont. Technical Coordinators: J.K Brown, R.M. Mutch, C.W. Spoon, and R.H. Wakimoto. U.S. For. Serv. Gen. Tech. Rep. INT-GTR-320. pp. 268-272.

U.S. Department of Agriculture. 2001. United States Forest Service Sierra Nevada Framework Project Environmental Impact Statement. U.S. Department of Agriculture, Pacific Southwest Region, Mare Island, Calif.

Veblen, T.T., Kitzberger, T., and Donnegan, J. 2000. Climatic and human influences on fire regimes in ponderosa pine forests in the Colorado Front Range. Ecol. Appl. 10: 1178-1195. 